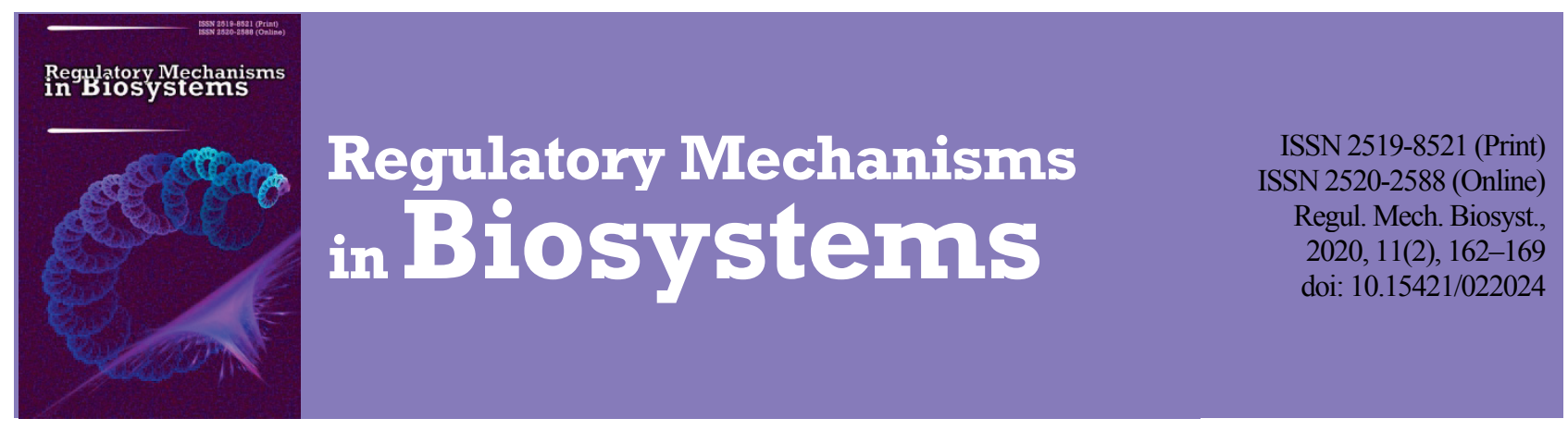

\title{
Retinol deficiency in animals: Etiopathogenesis and consequences
}

\author{
P. M. Skliarov*, S. Y. Fedorenko**, S. V. Naumenko**, O. V. Onischenko**, K. O. Holda* \\ *Dnipro State Agrarian and Economic University, Dnipro, Ukraine \\ **Kharkiv State Zooveterinary Academy, Kharkiv, Ukraine
}

Article info

Received 03.04.2020

Received in revised form 26.04.2020

Accepted 28.04.2020

Dnipro State Agrarian and Economic University Serhii Efremov st., 25, Dnipro, 49600, Ukraine. Tel.: +38-067-110-02-35. E-mail: skliarov.p.m@dsau.dp.ua

Kharkiv State

Zooveterinary Academy, Akademichna st., 1 , Mala Danylivka vil, Kharkiv reg., 62341, Ukraine. Skliarov, P. M., Fedorenko, S. Y., Naumenko, S. V., Onischenko, O. V., \& Holda, K. O. (2020). Retinol deficiency in animals: Eti-
opathogenesis and consequences. Regulatory Mechanisms in Biosystems, 11(2), 162-169. doi:10.15421/022024

Infertility is widespread for all species of animals and causes significant economic losses to livestock due to the loss and shortage of offspring, their reduced viability and, consequently, increased morbidity and mortality. Alimentary-deficiency factors are among the commonest causes of infertility, from which A-vitamin deficiency should be singled out. The precursor of vitamin A in the body is carotene, which is an unstable compound which is easily destroyed even under the influence of moderate factors of influence, in connection with which its deficiency is global, especially at the end of the winter - stall period of keeping animals. Accordingly it is the leading etiological factor of retinol deficiency infertility. As a result, the body has two negatives that act in parallel: carotene / vitamin A deficiency adversely affects the organs, the constituent and major functional unit of which is the secretory epithelial cell, and the free radical oxides formed in high concentration are extremely effective in destroying the cells, weakening antioxidant protection. Vitamin A has a significant effect on the reproductive function of animals both directly and indirectly. It is necessary to ensure the structure and functioning of the epithelial tissues of the organs of regulation and performance of sexual function, and therefore the physiological development of the fetus and the course of pregnancy, parturition and postpartum period, ovo- and spermiogenesis, the manifestation of sexual reflexes. Instead, its deficiency underlies the etiology and pathogenesis of retinol deficiency infertility of animals, causing changes in individual indices of homeostasis and prooxidate-antioxidant system, morphostructure of the reproductive and endocrine organs, hormonal status, sperm quality and reproductive function. The consequence is the emergence and development of gynecological, andrological, mammological and perinatal (ante-, intra-, post- and neo-) pathologies. At the same time, the addition of carotene or retinol to the diets of animals or their oral administration in cases of deficiency of vitamin A prevents impaired reproductive function. The study of the features of the etiopathogenesis of retinol deficiency infertility of animals allows programs of complex diagnostics, therapy and prevention to be developed which provide determination of carotene and vitamin A content and replenishment of the organism in cases of their deficiency.

Keywords: vitamin A; carotene; reproductive function; animals.

\section{Introduction}

Impaired reproductive function is an urgent problem not only in veterinary medicine but in human medicine also (Cederroth et al., 2010; Mascarenhas et al., 2012; Bidne et al., 2018). Infertility is widespread for all species of animals and causes significant economic losses to livestock due to the loss and under-production of the offspring, reduced viability and, consequently, increased morbidity and mortality (Pasynkova, 2010; Golumbijovs'ka \& Stefanyk, 2018; Medvedskij \& Mazolo, 2018).

There are many causes of infertility and they are very diverse (Iolchiev et al., 2014; Liu et al., 2015; Abdel-Rahman et al., 2018; Habeeb et al., 2018; Sharapa \& Bojko, 2019). However, among the most common factors are alimentary and deficient factors (Ferguson, 1991; Gnojevyj, 2006; Fedoruk et al., 2017; Ibtisham et al., 2018). Of these, Vitamin A deficiency should be singled out (Sommer, 2001; Porfir'ev, 2007; Darmenova et al., 2017; Wirth, 2017).

Research data suggest that vitamin A is involved in the processes underlying reproductive function, which is the basis for recommendations for the normalization of A-vitamin nutrition in animals (Godovanyj, 1982; Afanas'ev et al., 2005; Gnojevyj, 2006).

Studying the causes and mechanisms of development of retinol deficiency infertility in animals is the basis for the development of methods of diagnostics, therapy and prevention of pathologies caused by carotene / vitamin A deficiency (Koshovyj, 2008; Zaharenko et al., 2009; Kuz'minova et al., 2017; Shatohin, 2017; Devjatkin, 2018).

\section{Vitamin A and reproductive function}

Vitamin A has been known for over 100 years in the manifestation of reproductive function, but it remains the subject of extensive research (Guilbert et al., 1937; Davis \& Madsen, 1941; Wolf, 1996; Zile, 2001; Gromova et al., 2019).

The term "vitamin A" generalizes several groups of compounds - retinoids and carotenoids, the differences between which are associated mainly with completely different sources of organism and "places of their use" (Britton, 1995; Chacón-Ordóñez et al., 2019). Retinoids come into the body of some animals mainly with feed and the more fat they contain, the higher their concentration (Chung \& Wolgemuth, 2004; Harrison \& Curley, 2016). They play an exceptional role in stimulating growth and differentiation of cells (both embryo and adult organism), and one of the most important functions of retinoids is a pronounced antioxidant activity - their insufficiency increases the activity of free radicals (Ljubin \& Ljubina, 2013). This slows the development and differentiation of tissues in the fetus, disrupts the normal functioning of the placenta, which may delay intrauterine development. Therefore, based on the information on the intensity of research and development in the study of prooxidant-antioxidant mechanisms, in addition to the above, it should be noted that carotene has powerful antioxidant properties (Furr, 2004; Harrison \& Curley, 2016). Unlike retinoids, carotenoids enter the body with plant-based feed. Their deficiency in the body is manifested only with a concomitant deficiency of retinoids, as these compounds can interchange with each other 
under conditions of deficiency of one of them (Deming \& Erdman, 1999; Lu \& Li, 2008; Halik et al., 2016). As soon as stocks of both types of compounds are depleted, signs of their deficiency, commonly known as "vitamin A deficiency signs", appear. The precursor to vitamin A is $\beta$-carotene, while other carotenoids (lutein, zeoxanthin, violoxanthin, etc.) are less biologically active than $\beta$-carotene (Priyadarshani, 2017; Sergeev et al., 2017). Currently, many studies have been conducted to prove the biological importance of carotenoids, which is not associated with A-vitamin activity (Akordor et al., 1986; Ambrósio et al., 2006; Sommer \& Vyas, 2012). In the body, they act as antioxidants, exhibit antistress properties, affect the immune system and the stability of genetic material, increase immunocompetence and contact interaction of cells, at the cellular and molecular level prevent the transformation, induced by genotoxic substances, oxidants, $x$-rays. Carotenoids have been found to affect the endocrine system, especially associated with reproductive processes (von Euler et al., 1929; Goodwin, 1950; Wang et al., 1987).

If administered to animals with vitamin $\mathrm{A}$, overdose is possible, the $\beta$ carotene is not toxic at all. Vitamin A is synthesized in sufficient quantities, the rest of the $\beta$-carotene is used in other vital biological processes of the animal organism - this indicates the effectiveness of using $\beta$-carotene, not vitamin A. That is, complete provision of the body with Vitamin A in the absence of $\beta$-carotene will not solve the problem of infertility (Bindas et al., 1984; Olson, 1996; Green \& Fascetti, 2016).

It is unlikely that any other vitamin performs such an important function for the preservation of life and species as vitamin A (Dushejko, 1989; Hammerling, 2016; Debelo et al., 2017). This is confirmed by the synonyms accepted for its designation - a growth vitamin, anti-infective, which has a stimulating effect on oxidative processes in the body, promotes normalization different types of metabolism (Vlizlo et al., 2015; Darmenova et al., 2017; Biswas et al., 2018; Gromova et al., 2019). It is involved in the regulation of trophic processes and increased resistance of the body to infection, stimulates the growth and development of the body, protein biosynthesis, glycoproteins, steroid hormones, protects the skin and participates in ensuring normal vision. It is known that vitamin A influences the oxidation processes in the body, promotes the normalization of various types of metabolism (Doldo et al., 2015; Ljubina, 2015; Okechukwu et al., 2018). In this regard, the labile action of retinol on plasma and intracellular membranes and its involvement in the synthesis of lipid components of cell membranes is important. Retinol participates in regulation of trophic processes and increase of resistance of an organism to infections, stimulates growth and development of an organism, protein biosynthesis, glycoproteins, steroid hormones, influences metabolism of nucleic acids. In contrast, animals with Vitamin A deficiency have a decrease in ribosomal and transport RNA content (Chen et al., 2008; Erkelens \& Mebius, 2017; Baishnikova et al., 2018; Krishna et al., 2019).

In total, up to 50 disorders are reported that occur due to vitamin A deficiency and, most importantly, its positive effect on the function of animal reproduction, so retinol is not without reason called a reproduction vitamin (Haliloglu et al., 2002; Tanumihardjo, 2004; Gnojevyj, 2006; Madureira et al., 2016). The first reports about the role of vitamin A in animal reproduction have a long history (Bindas et al., 1984; Akordor et al., 1986; Graves-Hoagland et al., 1988). Although Vitamin A was discovered by Ma-Callum and Davis in 1913, it was not known until 1924, when Wisconsin researchers reported on the new work and gave an explanation of the first data. In numerous subsequent scientific works, it was established that the content in the body of the mother of sufficient amount of vitamin A ensures the normal development of the fetus, the course of pregnancy, parturition and the postpartum period (Bodansky et al., 1943; Petrov \& Evstaf'ev, 1976). Instead, its long-term deficits lead to a significant decrease in reproductive capacity (Porfir'ev, 2007; Koshovyj et al., 2008; Tanumihardjo, 2011; Thorne-Lyman \& Fawzi, 2012; Mccauley, 2015).

Insufficient vitamin A in the body disrupts the structure and function of the reproductive, endocrine organs and fetoplacental complex, which causes impaired zygote implantation processes, abortions, delayed fetal development, inhibition of structural and functional differentiation of their internal organs, development of antenatal hypotrophy and weakness of parturition (Zile, 2001; Koshovyj et al., 2008; Maia et al., 2019). Vitamin A deficiency is associated with the emergence and development of gynecological pathologies (Besedovs'kyj et al., 2012; Fedorenko et al., 2012).
In the absence of vitamin A and carotenoids, morphological changes in the breast are noted, causing changes in its function and quality of secreted milk (Chew et al., 1982; Johnston \& Chew, 1984; Oldham et al., 1991; Gomez et al., 2017).

The problem of insecurity of the body beta-carotene (vitamin A) is also relevant for males, causing morphofunctional changes in the organs of regulation and performance of sexual function (reducing the mass and size of organs, dystrophic processes and reducing the number of cells and hormone producers) and, accordingly, hypo- or impotence (Appling \& Chytil, 1981; Baleato et al., 2005; Hogarth \& Griswold, 2010; Koriem \& Arbid, 2018; Yon et al., 2019).

\section{Causes and pathogenesis of A-vitamin infertility}

Alimentary factors, compared to others, have the most pronounced effect on the metabolism of vitamin A, the main source for the synthesis of which in the body is carotene (Cao et al., 2019). The requirement of ruminants for vitamin A is fully ensured when grazing them in the summer in full-fledged pastures, and during the stalling period when consuming highquality hay, haying, silage (Dushkin, 2013). When grazing on high-quality pasture, reserves of vitamin A are created in the liver, which provide them with the need for this vitamin when it is deficient in the diet for 4 6 months (Majchrzak et al., 2006). Vitamin A supplies available in the liver for a long time provide for their need for this vitamin, and the symptoms of A-vitamin deficiency are only manifested when its reserves are exhausted. Under natural conditions, symptoms of A-avitaminosis are observed in grazing animals on low-yielding pastures in arid areas. In general, bypassing vitamin A in the liver when grazing in the spring in a fullfledged pasture sufficiently provides the basic physiological functions in their body, even with prolonged carotene deficiency in the diet (Eden, 1949).

The main source of vitamin A (carotene) for sheep is pasture grass, and in winter hay, silage, haying. So, their vitamin A problems are the same as in cows. In sheep farming, there are well-known cases of mass sheep disease, especially pregnant sheep at the end of pregnancy due to vitamin A deficiency. This is accompanied by the birth of dead lambs. Sheep with twins suffer especially. The same picture is observed in the lack of carotene in the diets of sheep, as evidenced by the lack of vitamin A in the liver of lambs (Gnojevyj, 2006).

With intensive pig farming, natural feeds do not completely satisfy the pigs' need for vitamin A for their carotene diet. This is especially true of suckling piglets, in which the body carotene does not transform into vitamin $\mathrm{A}$, so the rations of pigs must be enriched with ready concentrates of this vitamin. In the body of pigs with vitamin A deficiency, pathogens of various diseases are easier to penetrate, the resistance of the organism decreases, ovulation and fertilization are impaired, the number of stillbirths and deformed pigs is increased, the delay of placenta is observed. Insufficiency of vitamin $\mathrm{A}$ in sows during the period of fattening leads to the fact that piglets are born weak and die in the first days or become ill, poorly absorb the nutrients of the feed and grow slowly. Animals exprience the lack of vitamin A especially in the winter, because when feed is stored, provitamin A carotene loses its activity by about $10-20 \%$ per month (Kornienko \& Ulit'ko, 2016; Ghosh et al., 2019).

High-yielding animals require higher amounts of vitamin A because they are unable to completely convert carotene to vitamin A. Vitamin A content in organs and tissues of females and fetuses depends on the reproductive cycle and coincides with critical periods of pig embryonic development. This is especially true in the early stages of embryonic development, when their nourishment occurs at the expense of the embryophagus - the secretion of the uterine glands, which includes vitamin A. That is, the amount of vitamin A is closely linked to the intensity of growth and development of the embryo (Chew, 1993; Gnojevyj, 2006).

Insufficient supply of carotene to animals (especially those with high biological activity) is observed quite often and is of a global nature, and its concentration of carotene in blood plasma varies widely depending on diet, feeding conditions, season, breed, age, physiological and other features of the body (Davis \& Madsen, 1941; Olson, 1984; LeBlanc et al., 2004; Álvarez et al., 2015; Ashmawi et al., 2017).

Factors that determine carotene retention, absorption, and transformation into vitamin $\mathrm{A}$ : in the feeds is the type of canning, place of storage, 
storage time, stabilizer content, free fatty acids, inorganic substances; in the animal - health, absorption mechanisms, features of the gastrointestinal tract, inhibitory substances in the contents of the intestine or mucosa. Their effect is at different levels of metabolic conversion of vitamin A: absorption in the gastrointestinal tract; conversion of carotene to vitamin A, transport, deposition, tissue, cellular and subcellular distribution, utilization and excretion (Drummond et al., 1935; Dushejko, 1989; Blaner et al., 2016).

The absorption of vitamin A by the body of the animal depends primarily on the overall balance of the diet. Violations of the conditions of confinement and limited level of feeding of animals lead to functional pathology of organs and tissues and reduce the amount of vitamin deposited in the body (Lidén \& Eriksson, 2006; Harrison, 2012). Optimization of the structure of the diet, normalization of nitrogen and carbohydrate-fat metabolism, providing animals with minerals and vitamins can significantly increase the absorption of carotene. At the same time, the absorption is significantly influenced by the level of vitamin A reserves in the body, genetically determined activity of the hormonal system and other factors that determine the nature and intensity of metabolic processes (Eden \& Sellers, 1949; Ganguly, \& Sastry, 1985; Shete \& Quadro, 2013).

In many cases, the extent of carotene absorption is determined by the nature of the feed processing and storage conditions, which in turn is related to the different influence of technological means on the destruction of the protein-carotene complex existing in plant sources or on the isomerization processes of carotene (Moore, 1982; Harrison, 2005; Reboul, 2013). For example, ruminants, due to their biological and physiological characteristics, require the supply of vitamin A and its deficiency is especially widespread during the winter and winter-spring period of keeping animals. This is due, on the one hand, to the fact that the feeds that form the basis of the winter diet contain a small amount of carotene capable of being converted to vitamin A. On the other hand, carotene is a substance that is easily destroyed in the air, light, in a neutral or alkaline environment, significant losses occur as a result of violations of time, the mode of collecting and preservation of feed, as well as during their storage. In the summer, when green fodder is used, the animal's need for vitamin A is fully ensured and significant liver reserves are created (Glover, 1961; Bollag, 1981; Bohn et al., 2019).

Transformation into a vitamin and absorption of transformants into the blood depends on many conditions. These processes are reduced by the lack of protein and vitamins $E, D, B_{4}$ and $B_{12}$, due to the large number of nitrites, inclusion in the diet of feed and fish oil with a high acid number. The need for carotene and vitamin A is doubled or tripled in stress, diseases of different etiology and unbalanced feeding. On the other hand, due to the fact that carotene is a substance that is easily destroyed in air, light, in neutral and alkaline environments, large losses are due to breach of time, modes of collection and preservation of feed, as well as during their storage. Protein, trace elements and other vitamins, which have a stimulating effect on the metabolism of vitamin A in the gastrointestinal tract, liver and mammary gland, and have a regulatory effect on the conversion of carotene to vitamin A, play an important role in providing animals with retinol absorption from the blood by the breast, epithelium formation in the transport systems of the breast (Godovanyj, 1982; Dushejko, 1989; Porfir'ev, 2007; Rubin et al., 2017).

Therefore, hypovitaminosis A in the body of animals is most often recorded at the end of winter and spring, with insufficient intake of feed of carotene, which in the walls of the pancreas and liver is transformed into vitamin A. Deficient feeding is the most common cause of such immunodeficiency, cellular immunity, phagocytic function, complement system activity, antibody secretion, cytokinin synthesis (Murata et al., 2018). The magnitude and extent of impaired immune responses arising from insufficient nutrition and malnutrition depend on a number of factors, including the rate of cellular proliferation, the intensity of protein synthesis, and the importance of certain elements of consumption in major metabolic processes. For the functioning of many enzymes that play a major role in immune reactions, in addition to other substances, the need to enter the body of carotene (vitamin A), pronounced signs of insufficient income are hypotrophy, dystrophy, atrophy of lymphoid tissue (Olson, 1989; Koshovyj et al., 2008; Gul et al., 2015).

Beta-carotene is in feeds in the form of various isomers. Of all the carotene isomers (there are about 600), the largest output of vitamin A is the $\beta$-isomer, which has in its structure $2 \beta$-ion rings with symmetric carbohydrate chains, which is the basis of vitamin A. Under the influence of carotene oxygenase from one molecule carotene is formed by two carotene molecules, whereas from the $\alpha$ and $\gamma$ isomers only one molecule is formed. It is better to convert complete trans-beta-carotene, which has an elongated molecule shape, into vitamin A. Cis-form with one or two "curved" chain structure is only active for 20-50\%. Green plants contain mostly complete trans-beta-carotene. When dried or silage-fed, part of the complete trans-beta-carotene is converted to cis-form. Therefore, when using corn silage as the sole source of carotene in the diet, the animal's need for vitamin A is not met. The relatively low biological activity of corn silage on the one hand and the increased need for vitamin A for animals using this type of feed - on the other, is the main reason that under conditions of this type of feeding, the animals are in a state of hidden Ahypovitaminosis even at high supply of rations with carotene. In some cases, silage in the diet of cows is the only source of carotene, but in corn it is very low (up to $10 \%$ of carotene corn silage is converted to vitamin A). Yellow corn is only $30-50 \%$ of the total amount of carotene represented by $\beta$-carotene, while the dried and silage feeds contain fewer active isomers. In the corn silage in October, the green mass contains 4-7 times less carotene than in September. Alcohols formed in silage (sometimes up to $2.5 \%$ ) violate the liver's ability to metabolise vitamin A (Ribaya-Mercado et al., 1989; Müller et al., 2009; Kreißig et al., 2014).

At the same time, it is necessary to take into account the fact that vitamin A deficiency in the body of animals can be observed also with a sufficient amount of carotene in the diet. Thus, the reduction of carotene consumption and its conversion to vitamin A occurs under the action of organic acids, which enter the body in large quantities, as well as a significant content in the diet and in the organism of nitrates and nitrites (Emerick \& Olson, 1962; Goodrich et al., 1964; Wood et al., 1967; Lee \& Beauchemin, 2014; Khalil \& Hammad, 2019). Part of the salts of nitric acid goes into plants, getting into the body of animals it is restored to nitrates, and the latter inhibit the transformation of carotene to vitamin A. The destruction of carotene or vitamin $\mathrm{A}$ in acidic conditions is due to the action of gaseous nitric oxide on them, formed by low $\mathrm{pN}$ values the interaction of nitrates and oxygen. This explains the significant destruction of carotene in feed in the presence of nitrates. Therefore, the intensification of agrarian production, which involves the use of mineral fertilizers and herbicides in crop production, mineral additives, enzymes, technical fats in animal husbandry, contributes to the accumulation of these substances in the diet and thereby increases the animals'need for carotene / vitamin A (Weichenthal et al., 1963; Ross \& Zolfaghari, 2004; Koshovyj et al., 2008; Vlizlo et al., 2015). All of this ultimately leads to a decrease in feed intake, a significant reduction in the carotene content and vitamin $\mathrm{A}$ in animals (Koshovyj et al., 2008; Koshevoj et al., 2011; Naumenko, 2012; Shatohin et al., 2017).

The pathogenetic feature of hypo- and avitaminosis $\mathrm{A}$ is the slow development from the beginning of inferior carotene feeding of females. This is due to the fact that animals accumulate large amounts of vitamin A in the liver in the summer. Therefore, its deficiency should be determined long before the clinical picture of the disease is detected in the body (Levchenko \& Sahnjuk, 1997; Sommer, 2001; Blaner et al., 2016; Gomez et al., 2017).

Thus, in sheep, symptoms of A-avitaminosis are detected only by feeding them a diet deficient in vitamin A for 16-23 months. Vitamin A supplies available in the liver for a long time provide for their need for this vitamin, and the symptoms of A-avitaminosis occur in them only when its reserves are exhausted. In natural conditions, symptoms of A-avitaminosis in sheep are observed when grazing on low-yielding pastures in arid areas. In general, vitamin A stores in the liver of sheep when grazed in the spring on a full-fledged pasture sufficiently provide basic physiological functions in their body, even with prolonged carotene deficiency in the diet (Koshevoj et al., 2011).

Carotene/ vitamin A deficiency has a significant effect on the homeostasis state, causes impaired prooxidant-oxidant system with increased free radical oxidation and decreased antioxidant protection, leading to pathologies at the cellular level. Thus, according to biochemical studies in rabbit serum, there is a $46.6 \%$ decrease in vitamin A content, a 2.7 -fold increase in serum malondialdehyde concentration and $38.7 \%$ in erythro- 
cytes, a decrease of $36.9 \%$ catalase concentration and $26.9 \%$ superoxide dismutase in serum and $42.3 \%$ catalase concentration and $15.0 \%$ reduced glutathione in erythrocytes.

In the serum of cows during the dry period, prolonged carotene-deficient feeding reduced the carotene level by $70.0 \%$, vitamin A - by $75.0 \%$, catalase - by $43.7 \%$, superoxide dismutase - by $40.6 \%$ and increased malondialdehyde concentration - by $72.7 \%$. The concentration of catalase decreased by $41.7 \%$ in the erythrocytes and by $15.0 \%$ of the restored glutathione, and the level of malondialdehyde increased by $23.2 \%$ (Fedorenko et al., 2012).

Besedovs'kyj et al. (2012) report that cows with A-vitamin deficiency tend to decrease hemoglobin level by $8.3 \%$, total protein - by $8.3 \%$, calcium - by $8.2 \%$, inorganic phosphorus - by $14.2 \%$, acid capacity - by $24.1 \%$, copper - by $12.8 \%$, zinc - by $5.6 \%$ and cobalt - by $12.9 \%$, as well as vitamin A levels in the liver and serum - by $28.9 \%$ and $37.5 \%$ are observed.

Vitamin A deficiency in sheep with an increase in alkaline reserve of $7.1 \%$ or $15.5 \%$, decreased the number of erythrocytes by $1.0 \mathrm{~T} / \mathrm{L}$ or $12.6 \%$, hemoglobin content by $11.9 \mathrm{~g} / \mathrm{L}$ or $12.2 \%$, total protein $10.4 \mathrm{~g} / \mathrm{L}$ or $14.9 \%$, total calcium $0.25 \mathrm{mmol} / \mathrm{L}$ or $9.8 \%$, inorganic phosphorus $0.26 \mathrm{mmol} / \mathrm{L}$ or $15.6 \%$, vitamin $\mathrm{A}$ at $0.24 \mu \mathrm{mol} / \mathrm{L}$ or $27.0 \%$, zinc at $1.69 \mu \mathrm{mol} / \mathrm{L}$ or $10.4 \%$, cuprum at $1.2 \mu \mathrm{mol} / \mathrm{L}$ or $12.0 \%$ and cobalt at $0.04 \mu \mathrm{mol} / \mathrm{L}$ or $14.8 \%$ (Koshevoj et al., 2011).

Changes in vitamin A deficiency are based on impaired structure and function of lysosomal enzymes, impaired endocrine function. From a practical point of view, vitamin A is of great importance for the restoration and protection of the epithelial tissues of the mucous membranes of the reproductive organs and the excretory ducts of the glands. It is necessary for the functioning of mucous-producing cells and direct synthesis of mucopolysaccharides, so with deficiency of vitamin A, the epithelium of the mucous membranes is replaced by scaly cells that do not produce mucus. Many studies have been conducted to investigate the effect of vitamin A on the structure and function of the endocrine and genital apparatus in farm animals. Morphological and functional damage due to vitamin A deficiency occur primarily in those organs where the epithelial secretory cell is the main structural unit. The effects of vitamin A on the structure and function of the pituitary gland, thyroid and adrenal glands, ovaries, and uterus of cows and heifers have been fully covered. There are pronounced identical morpho-functional disorders in the organs of regulation and performance of reproductive function: adenohypophysis (mass reduction, deep dystrophic processes, "small cystic" dystrophy, desquamation and degranulation of basophils, low RNA content in the cytoplasm) adrenal glands (weight loss, cortical thickness, dystrophic phenomena, low lipid content, RNA in the cytoplasm), thyroid gland (weight loss, increase in follicular diameter, decrease in follicular epithelium height, increase in follicular lining their flat epithelium and filled with homogeneous colloid, desquamation and disintegration of the epithelium), uterus (dystrophic processes, desquamation of the epithelium, decrease in the number and size of uterine glands and mast cells, low RNA content in the cytoplasm) and cervical processes (dystrophy epithelium with completely "naked" sites, decrease in volume of secretion produced - predominance of neutral mucopolysaccharides over acidic, decrease of sialomucin and RNA content in epithelium), as well as placenta (destruction of stem and end villi, reduced number of giant cells, content of protein, RNA, glycogen, acidic mucopolysaccharides, increasing the permeability of structures for conditionally pathogenic microbes) and fetus (impaired structure and function of the feto-placental complex, inhibition of structural and functional differentiation of internal organs, reducing their potency development and occurrence of antenatal hypotrophy) (Koshovyj et al., 2008).

As a result, morphological changes occur in the relevant organs, including those that are regulators and performers of sexual function. Thus, the vitamin A deficiency decreases the length and width of the pituitary gland by $3.1-17.1 \%$ and $8.1-19.1 \%$ and the ovaries - by $20.0-28.3 \%$ and $32.0-46.6 \%$, as well as pituitary mass - by $14.0-23.2 \%$; the thyroid gland by $57.7-58.3 \%$, the adrenal glands - by $18.1-23.3 \%$ and the ovaries - by $54.8-84.9 \%$ in cows (Fedorenko et al., 2012).

According to Besedovs'kyj et al. (2012) for vitamin A deficiency, the pituitary gland of the cows was characterized by a decrease in weight (by $8.7 \%$ ), length (by $17.4 \%$ ), width (by $11.2 \%$ ) and the number of gonado- tropocytes (by 17.5\%); thyroid gland - an increase in the diameter of the follicles (49.1\%), a decrease in the follicular epithelium (12.8\%), weight (7.2\%), length (15.8\%) and width (11.2\%); adrenal glands - by reducing their weight (by 15.3\%), length (left - by $15.2 \%$, right - by $8.2 \%$ and width: left - by $11.9 \%$, right - by $8.3 \%$ ), and thickness of the cortical layer (by $25.7 \%$ ); uterus - a decrease in the number of uterine glands per unit area (by $37.7 \%$ ), their diameter (by 15.3\%), the thickness of the epithelium of the uterine glands (by 19.9\%) and the thickness of the endometrium (by 36.6\%); ovaries - decrease in the number of primordial (by $46.0 \%$ ), growing (by 28.9\%) and vesicular (by 14.4\%) follicles in the absence of dominant, and the yellow body looked like a delineated structure, elongated weights with layers between them (Besedovs'kyj et al., 2012).

In sheep with vitamin A deficiency, compared to animals with normal homeostasis, the pituitary gland mass was lower $(-0.09 \mathrm{~g}$ or $-17.6 \%)$, thyroid $(-1.29 \mathrm{~g}$ or $-19.2 \%)$, and adrenal glands $(-0.35 \mathrm{~g}$ or $-8.9 \%)$, length $(-0.28 \mathrm{~cm}$ or $-14.7 \%)$, width $(-0.2 \mathrm{~cm}$ or $-18.2 \%)$ and weight $(-0.51 \mathrm{~g}$ or $-21.7 \%)$ of the ovaries, and smaller $(-1.60 \mathrm{~cm}$ or $-10.8 \%)$ and thickness $(-1.05 \mathrm{~cm}$ or $-12.7 \%)$ of horns and cervix $(-0.56 \mathrm{~cm}$ or $-9.7 \%)$ of the uterus. In addition, in animals with deficiency of vitamin A marked changes take place in the shape of the ovary (flattened-oval against oval or bean-shaped normal), the nature of its surface (smooth or with a slight hunchback, normal - hilly) and consistency (denser than normal). Similar changes in consistency were noted for the uterus and its cervix (Koshevoj et al., 2011).

A decrease in the mass and size of endocrine and reproductive glands in males due to vitamin A deficiency was established. Thus, the weight of the pituitary gland (by 8.6-23.1\%), thyroid (by 12.6-23.3\%), adrenal glands decreased. (by 13.3-15.2\%) and the testes (by 23.6\%). Accordingly, the size of the organs (width, length in total) also decreased: the pituitary gland (by $15.0-20.0 \%$ ), the thyroid gland (by $10.5 \%$ ), the adrenal glands (by 12.6-14.8\%), testes (by $23.7 \%$ ). In addition, significant morphological changes were revealed: in the pituitary gland - degranulation, dystrophy, desquamation and reduction of the number of gonadotropocytes per unit area (by $25.0 \%$ ); thyroid gland - increase in diameter (by $20.1 \%$ ) and the number of follicles lined by flat epithelium and filled with homogeneous colloid (without vacuoles), disintegration and desquamation of the epithelium of the follicles, decrease in height of their epithelium (by 17.4\%); adrenal glands - decrease in thickness of the cortical layer (by 23.3-25.6\%), dystrophic phenomena and poor cell differentiation.

In the testes was observed a decrease in their mass, the number of convoluted tubules, their distension, disintegration, dystrophy and desquamation of epithelial cells, as well as a significant decrease in the number of Leydig cells. Thus, prolonged and significant deficiency of vitamin A in dogs causes disturbance in the testis (a decrease of $19.1 \%$ by weight and by $17.5 \%$ - the size, as well as a decrease in the number of tortuous tubules, their overgrowth, disintegration, dystrophy and desquamation of epithelial cells, $40 \%$ decrease in Leydig cells) (Naumenko et al., 2012).

Accordingly, violations of the structure of organs cause changes in their function. In particular, hormone imbalance occurs in the organism of females due to A-vitamin deficiency. Thus, in cows there was a significant increase in progesterone levels - up to $36.0 \mathrm{nmol} / \mathrm{L}$ (10 times) and a decrease in estradiol levels - up to $1.28 \mathrm{pg} / \mathrm{mL}$ (3 times) (Besedovs'kyj et al., 2012), in sheep - a decrease in the concentration of sex hormones - estriol by $0.14 \mathrm{pg} / \mathrm{mL}$ or $17.7 \%$ and progesterone by $0.08 \mathrm{nmol} / \mathrm{L}$ or $6.6 \%$ (Koshevoj et al., 2011). In males, impaired endocrine function of the testes (androgenesis) leads to a decrease in testosterone concentration (by 42.8 $47.2 \%$ ), as well as inhibition of sexual reflexes and a decrease in sperm quality - a decrease in ejaculate volume (by 18.1-42.1\%), motility (by $5.3-23.1 \%$ ) and concentration (by $5.3-15.0 \%$ ) of sperm, increase in the number of sperm with morphological anomalies (by 1.1-1.9 times or up to $45.0 \%$ ) (Naumenko, 2012).

Topical and well-studied are the effects of vitamin A on the morphological and functional state of the endometrium in animals during embryo implantation (Koshovyj et al., 2008; Gromova et al., 2019). Vitamin A increases endometrial functional activity during zygote implantation, increases protein and progesterone levels, prevents embryonic mortality. Vitamin A and carotene are found in the placenta in significant amounts, indicating that they are deposited in this organ. Toward the fetus, the placental barrier is overcome only by carotene, which in the liver is converted 
to vitamin A and deposited. Many studies have been devoted to fetal vitamin A availability and retinol penetration through the placenta. A number of authors are of the opinion that the content of vitamin $\mathrm{A}$ is low in the fetus, and that its reserves are directly dependent on the supply from the mother's body. It is suggested that some of the vitamin A in pregnant women is transferred from mother to fetus. This transfer is regulated by two mechanisms, one of which limits the transport of vitamin A from the mother to the fetus with sufficient or excess of its content in the mother's body, and the other ensures the retinol transfer to the fetus at its insufficiency by mobilizing the maternal organism's resources (MorrissKay, 1995; Gnojevyj, 2006).

Vitamin A deficiency leads to significant histostructural changes in the endometrium; disorders of the structure of the stroma and uterine glands, narrowing of the lumen of the glands, desquamation of the epithelium; reduction of glycogen content and alkaline phosphatase, acidic mucopolysaccharides are not detected. A noticeable decrease in morphometric parameters: decrease in the thickness of the uterine mucosa, height of the epithelium of the endometrium and epithelium of the uterine glands, decrease in the number of uterine glands and their diameter. There is also a significant decrease in the number of plasma and mast cells in the uterine mucosa. The content of RNA in the plasma of these cells decreases, their agranularity is observed. The functional epithelium of the uterine mucosa and its glands is transformed into a non-differentiated multilayered flat, which causes a sharp decrease in the secretion of the uterine glands, as well as changes in the composition of the embryotroph (Ross et al., 2000). Metaplasmic hyperkeratosis of the mucous membrane of the cervix is observed, which creates unfavourable conditions for the fertilization and implantation of blastocysts, impairs the development of the embryo, causes the death of embryos, increases sensitivity to infection of the mucous membranes, atrophy, disorders of the sexual cycles, preterm birth, stillbirth or delayed placenta, lactation disorders, etc. (Koshovyj et al., 2008).

Particularly noteworthy is the fact of the negative effect of vitamin A deficiency in the body of pregnant animals on the structure and function of the fetoplacental complex. Thus, vitamin A deficiency causes significant micro- and macromorphological changes in the placenta. They are characterized by a decrease in the mass and size of the placenta, a decrease in the area of the villous chorion (infarction), disturbance of its structure, atrophy, destruction of end and stem villi, dystrophy and desquamation of the epithelium of villi, decrease in the number of giant cells, dystrophin cells content of glycogen and RNA, decrease in the number of capillaries and disorders of hemocirculation, detachment of the fetal placenta (Haliloglu et al., 2002; Mccauley, 2015; Maia et al., 2019).

Vitamin A deficiency disrupts the structure and function of the ovaries, adrenal glands, that is, those organs that produce maternal dehydroepiandrosterone sulfate at the beginning of pregnancy. This condition is one of the reasons for the decrease in the level of dehydroepiandrosterone sulfate, the precursor of estrogens. Consistently conducted studies have found that hypotrophy of the adrenal glands of the fetus develops with A-vitamin deficiency and, as a consequence, their functional activity decreases. There is also a decrease in the functional activity of the liver of the fetus. That is, changes occur in those organs that produce fetal dehydroepiandrosterone sulfate. Transformation of dehydroepiandrosterone sulfate into estrogens is carried out in the placenta, however, and in this organ significant deficiencies of structure and function occur in vitamin A deficiency (Koshovyj et al., 2008; Thorne-Lyman \& Fawzi, 2012; Gromova, 2019).

Genital epithelium has been found to show signs of degeneration due to vitamin A deficiency at a time when they are not yet present in the epithelium of other organs. Vitamin A deficiency leads to significant histostructural changes in the endometrium - sparse stroma and uterine glands, narrowing of the lumen of the glands, desquamation of the epithelium, decrease in glycogen content and alkaline phosphatase, while acidic mucopolysaccharides are not detected. Thus, cows decreased the number of uterine glands per unit area (by 37.7-37.9\%), their diameter (by 15.3$18.2 \%$ ), the thickness of the uterine epithelium of the glands (by 13.6 $19.9 \%$ ) and endometrial thickness (by 36.6-37.2\%) (Besedovs'kyj et al., 2012; Fedorenko et al., 2012).

Studies have shown that deficiency in the diet of carotene, as well as the resulting A-vitamin deficiency leads to impaired growth of the fetus and abortion, the birth of dead, non-viable animals. For example, in bit- ches with vitamin A deficiency, the placenta was characterized by a decrease in size: length $(4.5 \%)$, width $(6.5 \%)$, mass $(18.5 \%)$ and area $(10.7 \%)$, as well as a change in structure, a decrease in collagen content and elastic fibers, detection of areas of hemosiderin. Histological examinations revealed significant morphofunctional changes in the organs of the platelets (thyroid, liver, adrenal glands, ovaries, uterus, and choral part of the placenta). Thus, in their liver, the phenomena of dystrophy, low hemopoiesis, large areas of hemolysis of erythrocytes were established; adrenal glands were characterized by poor differentiation and decreased height of the cortical layer; morphofunctional changes were noted in the thyroid gland, and large follicles $(0.048 \mathrm{~mm})$ lined by flat epithelium were marked on the histo-sections; at the sections of the ovaries were sometimes observed primordial follicles (at the stage of formation), and no uterine glands were detected in the uterus. As a result, puppies at the 58th day of development had reduction in body weight of $17.3 \%$, as well as organs: thyroid $(55.5 \%)$, spleen $(37.5 \%)$, adrenal glands $(30.0 \%)$, liver $(29.5 \%)$, brain (29.1\%), uterus with ovaries (31.2\%) revealed (Koshovyj et al., 2008).

The lack of vitamin A in sheep disrupts the formation of the fetoplacental complex, which is accompanied by changes in the structure of the placenta, atrophy and destruction of the terminal villi, dystrophy and desquamation of the epithelium of the villi. In this case, the mass of the placenta decreases by $21.8 \%$ and the area of the villous chorion - by $12.2 \%$, as well as the mass of fetus - by $17.2 \%$ and the organs -of the heart by $3.6 \%$, of the lungs by $5.7 \%$, of the stomach with intestines by $13.8 \%$, of the liver by $20.9 \%$, of the kidneys by $8.9-10.3 \%$, of the spleen by $27.1 \%$, of the brain by $7.8 \%$, of the thyroid by $21.0 \%$ and of the adrenal glands by $16.7 \%$ and of the uterus with ovaries by $6.4 \%$ (Koshevoj et al., 2011).

The organ where the main structural unit is the epithelial secretory cell is the mammary gland. There are changes occurring in it, characterized by disturbance of the plasma membrane, changes in intercellular contacts and expansion of the size of the intercellular space, dystrophy of cells and their joining into the cavity of the mammary alveoli. There is a decrease in the area of secretory tissue and, conversely, an increase in connective tissue. This reduces the area of alveolar epitheliocytes and secretory tissue by increasing the connective tissue, observed vacuoles in the cytoplasm, destruction of membranes, exit of the nucleus from the cytoplasm, disintegration of cells with less intense staining, karyolysis, and karyopicnosis, weakly expressed cytoplasmic granulation, decrease in the number of plasma and mast cells, their area and increase of nuclear-plasma index. Therefore, the morphological and functional damage due to vitamin A deficiency also occurs here first, causing the phenomena of alveolocyte dystrophy and desquamation. Against this background, unless milk is removed from the alveolar cavity, degenerative processes deepen in the secretory epithelium leading to its involution and lactation arrest (Tjoelker et al., 1990; Shih \& Mahova, 2015; Welsch et al., 2018).

In the smears of the secretion of the mammary gland of cows with carotene and vitamin deficiency, an increase in the number of germs (by $88.0 \%$ ) and somatic cells with a slight predominance of epitheliocytes, a decrease in cell area and an increase in the nuclear-plasma index were established. The described changes confirm the presence of dystrophic processes in the breast. There is a vacuolation of the plasma, its weak colour, a change of forms, the exit of the nuclei beyond the cells, the formation of epitheliocyte symplasts (Koshevoj et al., 2015).

Accordingly, vitamin A deficiency causes diseases in the intra-, postand neonatal periods, as well as andro-, mamo- and gynecological pathologies. In particular, the pathogenesis of ovariopathies in cows, antenatal hypotrophy of calves, pigs, lambs, kids and puppies, as well as impairred reproductive function in males (dogs, boars and bulls) with vitamin A deficiency, were determined (Koshovyj et al., 2008; Besedovs'kyj et al., 2012; Fedorenko et al., 2012; Naumenko, 2012; Koshevoj et al., 2015).

At the same time, the addition of carotene or retinol to the diet or peroral administration of vitamin A deficiency prevents impaired reproductive function - for perinatal pathology (Koshovyj et al., 2008; Skljarov, 2013; Shatohin, 2017), endometritis (Gorjakin, 1973; Jiang et al., 2018), hypoluteolysis (Besedovs'kyj et al., 2012), hypogonadism (Fedorenko et al., 2012), retained placenta (Akar \& Gazioglu, 2006), mastodystrophy (Oldham et al., 1991; Koshovyj et al., 2015), testodystrophy and hypopotention (Huang \& Hembree, 1979; Naumenko, 2012; Bagmanov \& Iskandarov, 2016), and other reproductive disorders (Godovanyj, 1982; 
Chew, 1993; Aréchiga et al., 1998; Zaharenko et al., 2009; Tojgil'din et al., 2012).

\section{Conclusion}

Thus, vitamin A has a significant effect on the reproductive function of animals both directly and indirectly. This vitamin is necessary for ensuring the structure and functioning of the epithelial tissues of the organs of regulation and performance of sexual function, and therefore the physiological development of the fetus, the course of pregnancy, parturition and the postpartum period.

Instead, its deficiency is at the basis of the etiology and pathogenesis of the retinol deficiency infertility of animals, resulting in changes in individual indices of homeostasis and prooxidate-antioxidant system, morphostructure of the reproductive and endocrine organs, hormonal status, sperm quality and reproduction. The consequence is the emergence and development of gynecological, andrological, mammological and perinatal (ante-, intra-, post- and neo-) pathologies. At the same time, the addition of carotene or retinol to the diet or peroral administration of vitamin A deficiency prevents impaired reproductive function.

The study of the features of the etiopathogenesis of retinol deficiency infertility of animals allows development of programs of complex diagnostics, therapy and prevention, which can determine the content of carotene and vitamin A and replenish the organism of animals subject to retinol deficiency.

\section{References}

Abdel-Rahman, G. H., El-Hallawany, H. A., \& Dohreig, R. A. (2018). Effect of excess fluoride on reproductive potentials in farm animals (ovine). Alexandria Journal for Veterinary Sciences, 57(2), 41-57.

Afanas'ev, V., Solomaha, N., \& Ivanov, A. (2005). A-vitaminnoe pitanie korov [A-vitamin nutrition of cows]. Zhivotnovodstvo Rossii, 5, 50-51 (in Russian).

Akar, Y., \& Gazioglu, A. (2006). Relationship between vitamin A and beta-carotene levels during the postpartum period and fertility parameters in cows with and without retained placenta. Bulletin of the Veterinary Institute in Puławy, $50(1), 93-96$.

Akordor, F. Y., Stone, J. B., Walton, J. S., Leslie, K. E., \& Buchanan-Smith, J. G. (1986). Reproductive performance of lactating Holstein cows fed supplemental $\beta$-carotene. Journal of Dairy Science, 69(8), 2173-2178.

Álvarez, R., Meléndez-Martínez, A. J., Vicario, I. M., \& Alcalde, M. J. (2015). Carotenoid and vitamin A contents in biological fluids and tissues of animals as an effect of the diet: A review. Food Reviews International, 31(4), 319-340.

Ambrósio, C. L. B., Campos, F. A. C. S., \& Faro, Z. P. (2006). Carotenoids as an alternative against hypovitaminosis A. Revista de Nutrição, 19(2), 233-243.

Appling, D. R., \& Chytil, F. (1981). Evidence of a role for retinoic acid (vitamin A-acid) in the maintenance of testosterone production in male rats. Endocrinology, 108(6), 2120-2123.

Aréchiga, C. F., Vazquez-Flores, S., Ortiz, O., Hernandez-Ceron, J., Porras, A., McDowell, L. R., \& Hansen, P. J. (1998). Effect of injection of $\beta$-carotene or vitamin $\mathrm{E}$ and selenium on fertility of lactating dairy cows. Theriogenology, 50(1), 65-76.

Ashmawi, S. S., Riad, N. M., \& Saeed, M. A. (2017). Assessment of serum retinol-binding protein-4 levels in patients with acute exacerbation of chronic obstructive disease at intensive care unit. Egyptian Journal of Chest Diseases and Tuberculosis, 66(4), 739-743.

Bagmanov, M. A., \& Iskandarov, D. V. (2016). Vlijanie "Karolina" na kachestvennye i kolichestvennye pokazateli spermy bykov-proizvoditelej [The influence of "Carolin" on the qualitative and quantitative indicators of sperm of bulls]. Uchenye Zapiski Kazanskoj Gosudarstvennoj Akademii Veterinarnoj Mediciny imeni N. J. Baumana, 226(2), 22-26 (in Russian).

Baishnikova, I. V., Uzenbaeva, L. B., Iljuha, V. A., Kizhina, A. G., Pechorina, J. F., \& Il'ina, T. N. (2018). Lejkocity krovi i morfometricheskie parametry limfocitov pri razlichnyh dozah vitaminov A i E u amerikanskih norok (Neovison vison) [Blood leukocytes and morphometric parameters of lymphocytes at different doses of vitamins $\mathrm{A}$ and $\mathrm{E}$ in american minks (Neovison vison)]. Trudy Karel'skogo Nauchnogo Centra Rossijskoj Akademii Nauk, 12, 125-132 (in Russian)

Baleato, R. M., Aitken, R. J., \& Roman, S. D. (2005). Vitamin A regulation of BMP4 expression in the male germ line. Developmental Biology, 286(1), 78-90.

Besedovs'kyj, V. P., Koshevoj, V. P., \& Balym, J. P. (2012). Gipoljuteoliz u koriv i telyc': Diagnostyka, terapija ta profilaktyka [Hypoluteolysis in cows and heifers: Diagnosis, therapy and prevention]. Redakcijno-Vydavnychyj Viddil Harkivs'koji Derzhavnoji Zooveterynarnoji Akademiji, Harkiv (in Ukrainian).
Bidne, K. L., Dickson, M. J., Ross, J. W., Baumgard, L. H., \& Keating, A. F. (2018). Disruption of female reproductive function by endotoxins. Reproduction, 155(4), 169-181.

Bindas, E. M., Gwazdauskas, F. C., Aiello, R. J., Herbein, J. H., McGilliard, M. L., \& Polan, C. E. (1984). Reproductive and metabolic characteristics of dairy cattle supplemented with $\beta$-carotene. Journal of Dairy Science, 67(6), 1249-1255.

Biswas, R., Chakraborti, G., Mukherjee, K., Bhattacharjee, D., Mallick, S., \& Biswas, T. (2018). Retinol levels in serum and chronic skin lesions of atopic dermatitis. Indian Journal of Dermatology, 63(3), 251-254.

Blaner, W. S., Li, Y., Brun, P. J., Yuen, J. J., Lee, S. A., \& Clugston, R. D. (2016). Vitamin A absorption, storage and mobilization. In: Asson-Batres, M., Rochette-Egly, C. (Eds.). The biochemistry of retinoid signaling II. Subcellular biochemistry, Dordrecht. Pp. 95-125.

Bodansky, O., Lewis, J. M., \& Lillienfeld, M. C. (1943). The concentration of vitamin A in the blood plasma during pregnancy. The Journal of Clinical Investigation, 22(5), 643-647.

Bohn, T., Desmarchelier, C., El, S. N., Keijer, J., van Schothorst, E., Rühl, R., \& Borel, P. (2019). $\beta$-carotene in the human body: Metabolic bioactivation pathways - from digestion to tissue distribution and excretion. Proceedings of the Nutrition Society, 78(1), 68-87.

Bollag, W. (1981). From vitamin A to retinoids: Chemical and pharmacological aspects. In: Orfanos, C. E., Braun-Falco, O., Farber, E. M., Grupper C., Polano, M. K., \& Schuppli, R. (Eds.). Retinoids. Springer, Berlin, Heidelberg. Pp. 5-11.

Britton, G. (1995). Structure and properties of carotenoids in relation to function. The FASEB Journal, 9(15), 1551-1558.

Cao, D. X., Wang, S. L., Wang, R., Chai, S. T., Liu, S. J., \& Hao, L. Z. (2019). Changes of $\beta$-carotene and retinol levels and $\mathrm{BCO} 1$ gene and protein expressions in yak tissues at different nutritional seasons. Journal of Animal and Feed Sciences, 28(2), 120-127.

Cederroth, C. R., Auger, J., Zimmermann, C., Eustache, F., \& Nef, S. (2010). Soy, phyto-oestrogens and male reproductive function: A review. International Journal of Andrology, 33(2), 304-316.

Chacón-Ordóñez, T., Carle, R., \& Schweiggert, R. (2019). Bioaccessibility of carotenoids from plant and animal foods. Journal of the Science of Food and Agriculture, 99(7), 3220-3239.

Chen, X., Esplin, B. L., Garrett, K. P., Welner, R. S., Webb, C. F., \& Kincade, P. W. (2008). Retinoids accelerate B lineage lymphoid differentiation. The Journal of Immunology, 180(1), 138-145.

Chew, B. P. (1993). Effects of supplemental $\beta$-carotene and vitamin A on reproduction in swine. Journal of Animal Science, 71(1), 247-252.

Chew, B. P., Hollen, L. L., Hillers, J. K., \& Herlugson, M. L. (1982). Relationship between vitamin $A$ and $\beta$-carotene in blood plasma and milk and mastitis in Holsteins. Journal of Dairy Science, 65(11), 2111-2118.

Chung, S. S. W., \& Wolgemuth, D. J. (2004). Role of retinoid signaling in the regulation of spermatogenesis. Cytogenetic and Genome Research, 105, 189-202

Darmenova, A. G., Jusupov, S. R., \& Zuhrabov, M. G. (2017). Sostojanie Avitaminnogo obmena i ego vlijanie na vosproizvoditel'nuju funkciju korov [The state of A-vitamin metabolism and its effect on the reproductive function of cows]. Izvestija Orenburgskogo Gosudarstvennogo Agrarnogo Universiteta, 67, 247-248 (in Russian).

Davis, R. E., \& Madsen, L. L. (1941). Carotene and vitamin A in cattle blood plasma with observations on reproductive performance at restricted levels of carotene intake: One figure. The Journal of Nutrition, 21(2), 135-146.

Debelo, H., Novotny, J. A., \& Ferruzzi, M. G. (2017). Vitamin A. Advances in Nutrition, 8(6), 992-994.

Deming, D. M., \& Erdman, J. W. (1999). Mammalian carotenoid absorption and metabolism. Pure and Applied Chemistry, 71(12), 2213-2223.

Devjatkin, V. A. (2018). Jeffektivnost' ispol'zovanija beta-karotina v kormlenii krupnogo rogatogo skota [Beta-carotene efficiency in cattle feeding]. Vestnik Ul'janovskoj Gosudarstvennoj Sel'skohozjajstvennoj Akademii, 42, 130136 (in Russian).

Doldo, E., Costanza, G., Agostinelli, S., Tarquini, C., Ferlosio, A., Arcuri, G., Passeri, D., Scioli, M. G., \& Orlandi, A. (2015). Vitamin A, cancer treatment and prevention: The new role of cellular retinol binding proteins. BioMed Research Iinternational, 2015, 624627.

Drummond, J. C., Bell, M. E., \& Palmer, E. T. (1935). Observations on the absorption of carotene and vitamin A. British Medical Journal, 3884, 1208.

Dushejko, A. A. (1989). Vitamin A: Obmen i funkcii [Vitamin A: Exchange and functions]. Naukova Dumka, Kiev (in Russian).

Dushkin, V. V. (2013). Sravnitel'nyj analiz frakcionnogo sostava karotina i pitatel'noj cennosti kukuruznogo silosa [Comparative analysis of the fractional composition of carotene and the nutritional value of com silage]. Vestnik Ul'janovskoj Gosudarstvennoj Sel'skohozjajstvennoj Akademii, 22, 64-69 (in Russian).

Eden, E. (1949). Vitamin A deficiency in farm animals. Veterinary Record, 61, 845-851.

Eden, E., \& Sellers, K. C. (1949). The absorption of vitamin A in ruminants and rats. Biochemical Journal, 44(3), 264-267. 
Emerick, R. J., \& Olson, O. E. (1962). Effect of nitrate and nitrite on vitamin A storage in the rat. The Journal of Nutrition, 78(1), 73-77.

Erkelens, M. N., \& Mebius, R. E. (2017). Retinoic acid and immune homeostasis: A balancing act. Trends in Immunology, 38(3), 168-180.

Fedorenko, S. J., Koshevoj, V. P., \& Balym, J. P. (2012). Gipogonadyzm u koriv i telyc': Diagnostyka, terapija ta profilaktyka [Hypogonadism in cows and heifers: Diagnosis, therapy and prevention]. Redakcijno-Vydavnychyj Viddil Kharkivs'koji Derzhavnoji Zooveterynarnoji Akademiji, Kharkiv (in Ukrainian)

Fedoruk, R., Iskra, R., \& Lesyk, Y. (2017). Reproductive function of an organism of cows and rabbits at adding to ration of citrates of microelements. Visnyk Agrarnoji Nauky, 10, 22-27.

Ferguson, J. D. (1991). Nutrition and reproduction in dairy cows. Veterinary Clinics of North America: Food Animal Practice, 7(2), 483-507.

Furr, H. C. (2004). Analysis of retinoids and carotenoids: Problems resolved and unsolved. The Journal of Nutrition, 134(1), 281-285.

Ganguly, J., \& Sastry, P. S. (1985). Mechanism of conversion of ß-carotene into vitamin A - central cleavage versus random cleavage. In: Bourne, G. H. (Ed.) World Nutritional Determinants. Karger Publishers, Basel. Pp. 198-220.

Ghosh, S., Adak, K., Saha, P., Upadhyay, S., Ghosh, A., Das, P., \& Chatterjee, A. (2019). Beta-carotene retention as retinol activity equivalent at different cooking and storage variants. International Food Research Journal, 26(1), 355-361.

Glover, J. (1961). The conversion of $\beta$-carotene into vitamin A. Vitamins and Hormones, 18, 371-386.

Gnojevyj, I. V. (2006). Godivlja i vidtvorennja pogolivja sil's'kogospodars'kyh tvaryn v Ukrajini [Feeding and reproduction of livestock in Ukraine]. Kontur, Kharkiv (in Ukrainian)

Godovanyj, V. P. (1982). Vplyv vitaminnyh preparativ na vidtvornu zdatnist' koriv [The effect of vitamin preparations on the reproductive capacity of cows]. Visnyk Sil's'kogospodars'koji Nauky, 4, 74-75 (in Ukrainian).

Golumbijovs'ka, T. V., \& Stefanyk, V. J. (2018). Porushennja vidtvornoji funkciji $\mathrm{u}$ suk ta metody diagnostyky [Impaired reproductive function in bitches and methods of diagnosis]. Naukovyj Visnyk L'vivs'kogo Nacional'nogo Universytetu Veterynarnoji Medycyny ta Biotehnologij imeni S. Z. Gzhyckogo, 83, 385-395 (in Ukrainian).

Gomez, M. E. V., Varas, S., \& Gimenez, M. S. (2017). Model of long-term vitamin A deficiency in the mammary gland of virgin rats. Open Access Library Journal, 4(9), 1-14.

Goodrich, R. D., Emerick, R. J., \& Embry, L. B. (1964). Effect of sodium nitrate on the vitamin A nutrition of sheep. Journal of Animal Science, 23(1), 100-104.

Goodwin, T. W. (1950). Carotenoids and reproduction. Biological Reviews, 25(4), 391-413.

Gorjakin, F. (1973). Primenenie vitamina A pri lechenii jendometritov [The use of vitamin A in the treatment of endometritis]. Molochnoe i Mjasnoe Skotovodstvo, 4, 27-28 (in Russian).

Graves-Hoagland, R. L., Hoagland, T. A., \& Woody, C. O. (1988). Effect of $\beta$ carotene and vitamin A on progesterone production by bovine luteal cells. Journal of Dairy Science, 71(4), 1058-1062.

Green, A. S., \& Fascetti, A. J. (2016). Meeting the vitamin A requirement: The efficacy and importance of $\beta$-carotene in animal species. The Scientific World Journal, 2016, 7393620.

Gromova, O. A., Torshin, I. J., Tetruashvili, N. K., Kodencova, V. M., \& Rudakov, K. V. (2019). Vitamin A v akusherstve: Fundamental'nye i klinicheskie issledovanija [Vitamin A in obstetrics: Basic and clinical research]. Medicinskij Alfavit, 1(1), 59-69 (in Russian)

Guilbert, H. R., Miller, R. F., \& Hughes, E. H. (1937). The minimum vitamin A and carotene requirement of cattle, sheep and swine. The Journal of Nutrition, 13(5), 543-564.

Gul, K., Tak, A., Singh, A. K., Singh, P., Yousuf, B., \& Wani, A. A. (2015). Chemistry, encapsulation, and health benefits of $\beta$-carotene - A review. Cogent Food and Agriculture, 1(1), 1018696

Habeeb, A. A. M., El-Tarabany, A. A., Gad, A. E., \& Atta, M. A. (2018). Negative effects of heat stress on physiological and immunity responses of farm animals. Agricultural Studies, 2(1), 1-18.

Halik, G., Lozicki, A., Dymnicka, M, Arkuszewska, E., Zielinska, M., \& Rutkowska, H. (2016). The effect of feeding ration, enriched in synthetic and natural beta-carotene on the selected indicators of health condition of the cows and on reproduction parameters. Annals of Warsaw University of Life Sciences SGGW. Animal Science, 55(2), 167-175.

Haliloglu, S., Baspinar, N., Serpek, B., Erdem, H., \& Bulut, Z. (2002). Vitamin A and $\beta$-carotene levels in plasma, corpus luteum and follicular fluid of cyclic and pregnant cattle. Reproduction in Domestic Animals, 37(2), 96-99.

Hammerling, U. (2016). Retinol as electron carrier in redox signaling, a new frontier in vitamin A research. Hepatobiliary Surgery and Nutrition, 5(1), 15-28.

Harrison, E. H. (2005). Mechanisms of digestion and absorption of dietary vitamin A. Annual Review of Nutrition, 25, 87-103.
Harrison, E. H. (2012). Mechanisms involved in the intestinal absorption of dietary vitamin A and provitamin A carotenoids. Biochimica et Biophysica Acta-Molecular and Cell Biology of Lipids, 1821(1), 70-77.

Harrison, E. H., \& Curley, R. W. (2016). Carotenoids and retinoids: Nomenclature, chemistry, and analysis. In: Asson-Batres, M., \& Rochette-Egly, C. (Eds.). The Biochemistry of Retinoid Signaling II. Subcellular Biochemistry. Springer, Dordrecht. Pp. 1-19.

Hogarth, C. A., \& Griswold, M. D. (2010). The key role of vitamin A in spermatogenesis. The Journal of Clinical Investigation, 120(4), 956-962.

Huang, H. F. S., \& Hembree, W. C. (1979). Spermatogenic response to vitamin A in vitamin A deficient rats. Biology of Reproduction, 21(4), 891-904.

Ibtisham, F., Nawab, A. A. M. I. R., Li, G., Xiao, M., An, L., \& Naseer, G. (2018). Effect of nutrition on reproductive efficiency of dairy animals. Medycyna Weterynaryjna, 74(6), 356-361.

Iolchiev, B. S., Kononov, V. P., Tadzhieva, A. V., Bagirov, V. A., D'jakevich, O. N., \& Mambetaliev, M. A. (2014). Faktory, vlijajushhie na uroven' vosproizvedenija korov v sovremennom molochnom skotovodstve [Factors affecting the level of reproduction of cows in modern dairy cattle breeding]. Agramaja Rossija, 12, 18-21 (in Russian).

Jiang, Y., Chen, L., Taylor, R. N., Li, C., \& Zhou, X. (2018). Physiological and pathological implications of retinoid action in the endometrium. Journal of Endocrinology, 236(3), 169-188.

Johnston, L. A., \& Chew, B. P. (1984). Peripartum changes of plasma and milk vitamin $A$ and $\beta$-carotene among dairy cows with or without mastitis. Journal of Dairy Science, 67(8), 1832-1840.

Khalil, A. M., \& Hammad, S. (2019). Effects of nitrate toxicity on vitamin A concentration and the thyroid gland status in albino rats. Ophthalmology Case Reports, 3, 34

Koriem, K. M., \& Arbid, M. S. (2018). Evaluating of $\beta$-carotene role in ameliorating of favism - induced disturbances in blood and testis. Journal of Complementary and Integrative Medicine, 15(3), 20170164

Kornienko, A. V., \& Ulit'ko, V. E. (2016). Biologicheskaja dostupnost' karotina iz raciona svinomatok ih produktivnost' pri raznom sootnoshenii v njom kal'cija i cinka [The bioavailability of carotene from the diet of sows, their productivity with different ratios of calcium and zinc]. Vestnik Ul'janovskoj Gosudarstvennoj Sel'skohozjajstvennoj Akademii, 35, 107-110 (in Russian).

Koshevoj, V. P., Fedorenko, C. J., Onyshhenko, O. V., Pasternak, A. M., \& Skljarov, P. M. (2015). Imunobiologija laktaciji u tvaryn [Immunobiology of lactation in animals]. Gerda, Dnipropetrovs'k (in Ukrainian)

Koshevoj, V. P., Skljarov, P. M., \& Naumenko, S. V. (2011). Problemy vidtvorennja ovec' i kiz ta shljahy jih vyrishennia [Problems of reproduction of sheep and goats and ways of their solution]. Gamalija, Kharkiv, Dnipropetrovs'k (in Ukrainian).

Koshovyj, V. P., Ivanchenko, M. M., Skljarov, P. M., Cymerman, O. O., \& Naumenko, S. V. (2008). Veterynama perynatologija [Veterinary Perinatology]. Vydavnyctvo Shejninoji J. V., Kharkiv (in Ukrainian).

Kreißig, F., Schäfer, C., \& Ulrich, J. (2014). Prevention of solvent mediated isomer transfer of carotenoids. Chemical Engineering and Technology, 37(8), $1358-1362$.

Krishna, T. H. A., Kamalraj, S., Anikisetty, M., Naidu, K. A., Surin, W. R., \& Jayabaskaran, C. (2019). Inhibition of thrombin, an unexplored function of retinoic acid. Biochemistry and Biophysics Reports, 18, 100636.

Kuz'minova, E. V., Semenenko, M. P., Koshhaev, A. G., \& Troshin, A. N. (2017) Biologicheskie funkcii karotinoidov pri vosproizvodstve krupnogo rogatogo skota [Biological functions of carotenoids in cattle reproduction]. Politematicheskij Setevoj Jelektronnyj Nauchnyj Zhurnal Kubanskogo Gosudarstvennogo Agramogo Universiteta, 129, 1124-1136 (in Russian).

LeBlanc, S. J., Herdt, T. H., Seymour, W. M., Duffield, T. F., \& Leslie, K. E. (2004). Peripartum serum vitamin E, retinol, and beta-carotene in dairy cattle and their associations with disease. Journal of Dairy Science, 87(3), 609-619.

Levchenko, V. I., \& Sahnjuk, V. (1997). Diagnostyka i likuvannja A-gipovitaminozu koriv [Diagnosis and treatment of A-hypovitaminosis in cows]. Veterynarna Medycyna Ukrajiny, 10, 23-24 (in Ukrainian).

Lidén, M., \& Eriksson, U. (2006). Understanding retinol metabolism: Structure and function of retinol dehydrogenases. Journal of Biological Chemistry, 281(19), 13001-13004.

Liu, Y., Tian, Y., Zhao, X., Jiang, S., Li, F., Zhang, Y., Zhang, X., Liu, Y., Zhu, J., \& Fang, F. (2015). Immunization of dogs with recombinant GnRH-1 suppresses the development of reproductive function. Theriogenology, 83(3), $314-319$.

Ljubin, N. A., Stecenko, I. I., \& Ljubina, E. N. (2013). Funkcional'noe sostojanie sistemy antioksidantnoj zashhity i svobodnoradikal'nogo okislenija u svinej v zavisimosti ot primenenija razlichnyh form vitamina A i beta-karotina [Functional state of the antioxidant defense system and free radical oxidation in pigs depending on the use of various forms of vitamin A and beta-carotene]. Vestnik Ul'janovskoj Gosudarstvennoj Sel'skohozjajstvennoj Akademii, 1(21), 54-59 (in Russian). 
Ljubina, E. N. (2015). Rol' mineral'nyh jelementov v reguljacii processov svobodnoradikal'nogo okislenija na fone primenenija preparatov vitamina A i beta-karotina [The role of mineral elements in the regulation of free radical oxidation processes with the use of vitamin A and beta-carotene preparations]. Vestnik Ul'janovskoj Gosudarstvennoj Sel'skohozjajstvennoj Akademii, 31, 64 - 68 (in Russian).

Lu, S., \& Li, L. (2008). Carotenoid metabolism: Biosynthesis, regulation and beyond. Journal of Integrative Plant Biology, 50, 778-785.

Madureira, A. M. L., Guida, T. G., Cerri, R. L. A., \& Vasconcelos, J. L. M. (2016). Effect of serum concentration of $\beta$-carotene at $\mathrm{AI}$ on productive and reproductive parameters in lactating Holstein cows. Journal of Animal Science, 94, 553-553.

Maia, S. B., Souza, A. S. R., de Caminha, M. F. C., da Silva, S. L., de Cruz, R. Sá B. L. C., dos Santos, C. C., \& Filho, M. B. (2019). Vitamin A and pregnancy. A narrative review. Nutrients, 11(3), 681.

Majchrzak, D., Fabian, E., \& Elmadfa, I. (2006). Vitamin A content (retinol and retinyl esters) in livers of different animals. Food Chemistry, 98(4), 704-710.

Mascarenhas, M. N., Flaxman, S. R., Boerma, T., Vanderpoel, S., \& Stevens, G. A. (2012). National, regional, and global trends in infertility prevalence since 1990: A systematic analysis of 277 health surveys. PLoS Medicine, 9(12), e1001356.

Mccauley, M. E., van den Broek, N., Dou, L., \& Othman, M. (2015). Vitamin A supplementation during pregnancy for maternal and newborn outcomes. Cochrane Database of Systematic Reviews, 11, CD008666.

Medvedskij, V. A., \& Mazolo, N. V. (2018). Gigienicheskie meroprijatija po profilaktike besplodija u krupnogo rogatogo skota i svinej [Hygiene measures for the prevention of infertility in cattle and pigs]. Vitebskaja Gosudarstvennaja Akademija Veterinamoj Mediciny, Vitebsk (in Russian).

Moore, T. (1982). LXXIX. Vitamin A and carotene. VI. The conversion of carotene to vitamin A in vivo. Nutrition Reviews, 40(9), 275-278.

Morriss-Kay, G. (1995). Retinoids and embryos. In: Degos, L., \& Parkinson, D. R. (Eds.) Retinoids in oncology. Springer, Berlin, Heidelberg. Pp. 43-53.

Müller, R., Bernhard, K., Giger, A., Moine, G., \& Hengartner, U. (2009). (E/Z) Isomeric carotenes. Pure and Applied Chemistry, 69(10), 2039-2046.

Murata, R., Sugimoto, M., Ikeda, S., Nakatsuji, Y., \& Kume, S. (2018). Effects of supplemental water-soluble $\beta$-carotene on IgA induction in the intestine and mammary glands of lactating mice. Trace Nutrients Research, 35, 52-57.

Naumenko, S. V., Koshevoj, V. P., \& Balym, J. P. (2012). Retynoldeficytna gipopotencija: Diagnostyka, terapija ta profilaktyka [Retinoldeficiency hypotension: Diagnosis, therapy and prevention]. Redakcijno-Vydavnychyj Viddil Kharkivs'koji Derzhavnoji Zooveterynamoji Akademiji, Kharkiv (in Ukrainian).

Okechukwu, N. G., Albert, N. E., Akunna, G. G., Finbarrs-Bello, E., Elizabeth, C. A., \& Ibegbu, O. A. (2018). Beta-carotene: Positive effect on oxidative stress, lipid peroxidation, insulin and leptin resistance induced by dietary fat consumption. Journal of Advances in Medicine and Medical Research, 27(1), 1-7.

Oldham, E. R., Eberhart, R. J., \& Muller, L. D. (1991). Effects of supplemental vitamin $\mathrm{A}$ or $\beta$-carotene during the dry period and early lactation on udder health. Journal of Dairy Science, 74(11), 3775-3781.

Olson, J. A. (1984). Serum levels of vitamin A and carotenoids as reflectors of nutritional status. Journal of the National Cancer Institute, 73(6), 1439-1444.

Olson, J. A. (1989). Provitamin A function of carotenoids: The conversion of $\beta$ carotene into vitamin A. The Journal of Nutrition, 119(1), 105-108.

Olson, J. A. (1996). Benefits and liabilities of vitamin A and carotenoids. The Journal of Nutrition, 126(4), 1208S-1212S.

Pasynkova, T. S. (2010). Besplodie korov - ushherb hozjajstvu [Cow infertility damage to the farm economy]. Mezhdunarodnyj Vestnik Veterinarii, (2), 25-27.

Porfir'ev, I. A. (2007). Metabolizm vitamina A i besplodie u vysokoproduktivnyh molochnyh korov pri nesbalansirovannosti racionov [Vitamin A metabolism and infertility in highly productive dairy cows with unbalanced diets]. Sel'skohozjajstvennaja Biologija, 42(4), 83-95 (in Russian).

Priyadarshani, A. M. B. (2017). A review on factors influencing bioaccessibility and bioefficacy of carotenoids. Critical Reviews in Food Science and Nutrition, 57(8), 1710-1717.

Reboul, E. (2013). Absorption of vitamin A and carotenoids by the enterocyte: Focus on transport proteins. Nutrients, 5(9), 3563-3581.

Ribaya-Mercado, J. D., Holmgren, S. C., Fox, J. G., \& Russell, R. M. (1989). Dietary $\beta$-carotene absorption and metabolism in ferrets and rats. The Journal of Nutrition, 119(4), 665-668.

Ross, A. C., \& Zolfaghari, R. (2004). Regulation of hepatic retinol metabolism: Perspectives from studies on vitamin A status. The Journal of Nutrition, 134(1), 269-275.

Ross, S. A., McCaffery, P. J., Drager, U. C., \& De Luca, L. M. (2000). Retinoids in embryonal development. Physiological Reviews, 80(3), 1021-1054.

Rubin, L. P., Ross, A. C., Stephensen, C. B., Bohn, T., \& Tanumihardjo, S. A. (2017). Metabolic effects of inflammation on vitamin A and carotenoids in humans and animal models. Advances in Nutrition, 8(2), 197-212.
Sergeev, A. V., Anan'ev, V. S., Kapitanov, A. B., Korostelev, S. A., Bukreev, Y. M., Vlasenkova, N. K., Prosalkova, I. R., Reshetnikova, V. V., \& Shubina, I. Z. (2017). Pharmacokinetics of carotenoids and carotene containing compounds. Russian Journal of Biotherapy, 16(3), 92-106.

Sharapa, G. S., \& Bojko, O. V. (2019). Problemy statevoi’ cyklichnosti ta zaplidnennja telyc' i koriv [Problems of sexual cyclicity and fertilization of calves and cows]. Rozvedennja i Genetyka Tvaryn, 57, 192-198 (in Ukrainian).

Shatohin, P. P., Suprunenko, K. V., Karysheva, L. P., Derenchuk, J. I., \& Krylevec', J. V. (2017). Korekcija vmistu vitaminu A i cynku u syrovatci krovi kobyl ostann'ogo trymestru zherebnosti za alimentarnoji nedostatnosti [Korektsiya at the time of vitamin $\mathrm{A}$ and zinc at the blood of the blood of the remaining trimester of foals for nutritional deficiencies]. Visnyk Poltavs'koji Derzhavnoji Agrarnoji Akademiji, 3, 96-100 (in Ukrainian).

Shete, V., \& Quadro, L. (2013). Mammalian metabolism of $\beta$-carotene: Gaps in knowledge. Nutrients, 5(12), 4849-4868.

Shih, E., \& Mahova, A. (2015). Karotinoidy i zabolevanija molochnoj zhelezy s pozicij dokazatel'noj mediciny [Carotenoids and breast diseases from the perspective of evidence-based medicine]. Vrach, 12, 2-6 (in Russian).

Skljarov, P. M. (2013). Vplyv vitaminu A na morfologichnyj stan placenty i ploda $\mathrm{u}$ kiz [Effect of vitamin A on the morphological status of the placenta and fetus in goats]. Visnyk Poltavs'koji Derzhavnoji Agrarnoji Akademiji, 1, 113115 (in Ukrainian).

Sommer, A., \& Vyas, K. S. (2012). A global clinical view on vitamin A and carotenoids. The American Journal of Clinical Nutrition, 96(5), 1204-1206.

Tanumihardjo, S. A. (2004). Assessing vitamin A status: Past, present and future. The Journal of Nutrition, 134(1), 290-293.

Tanumihardjo, S. A. (2011). Vitamin A: Biomarkers of nutrition for development. The American Journal of Clinical Nutrition, 94(2), 658-665.

Thorne-Lyman, A. L., \& Fawzi, W. W. (2012). Vitamin A and carotenoids during pregnancy and maternal, neonatal and infant health outcomes: A systematic review and meta-analysis. Paediatric and Perinatal Epidemiology, 26, 36-54.

Tjoelker, L. W., Chew, B. P., Tanaka, T. S., \& Daniel, L. R. (1990). Effect of dietary vitamin $\mathrm{A}$ and $\beta$-carotene on polymorphonuclear leukocyte and lymphocyte function in dairy cows during the early dry period. Journal of Dairy Science, 73(4), 1017-1022.

Tojgil'din, S. V., Lifanova, S. P., \& Desjatov, O. A. (2012). Vlijanie biopreparata 'Kartok" na molochnuju produktivnost' i vosproizvoditel'nuju sposobnost' korov raznyh porod [The influence of the biological product “Kartok" on milk productivity and reproductive ability of cows of different breeds]. Vestnik Ul'janovskoj Gosudarstvennoj Sel'skohozjajstvennoj Akademii, 1, 17 (in Russian).

Vlizlo, V. V., Kurtjak, B. M., Vudmaska, I. V., Vishhur, O. I., \& Petruk, A. P. (2015). Zhyrorozchynni vitaminy u veterynarnij medycyni ta tvarynnyctvi [Fat-soluble vitamins in veterinary medicine and animal husbandry]. Spolom, L'viv (in Ukrainian).

Wang, J. Y., Hafi, C. B., Owen, F. G., \& Larson, L. L. (1987). Effect of betacarotene supplementation on periparturient health and reproduction of Holstein cows. Animal Reproduction Science, 15(1-2), 139-144.

Weichenthal, B. A., Embry, L. B., Emerick, R. J., \& Whetzal, F. W. (1963). Influence of sodium nitrate, vitamin A and protein level on feedlot performance and vitamin A status of fattening cattle. Journal of Animal Science, 22(4), 979-984.

Welsch, C. W., Zile, M. H., \& Cullum, M. E. (2018). Retinoids and mammary gland tumorigenesis: A critique. In: Reddy, B. S. (Ed.). Diet, nutrition and cancer: A critical evaluation. CRC Press. Pp. 1-22.

Wirth, J. P., Petry, N., Tanumihardjo, S. A., Rogers, L. M., McLean, E., Greig, A., Garrett, G. S., Klemm, R. D., \& Rohner, F. (2017). Vitamin A supplementation programs and country-level evidence of vitamin A deficiency. Nutrients, 9(3), 190.

Wolf, G. (1996). A history of vitamin A and retinoids. The FASEB Journal, 10(9), 1102-1107.

Wood, R. D., Chaney, C. H., Waddill, D. G., \& Garrison, G. W. (1967). Effect of adding nitrate or nitrite to drinking water on the utilization of carotene by growing swine. Journal of Animal Science, 26(3), 510-513.

Yon, J. M., Kim, J. S., Lin, C., Park, S. G., Gwon, L. W., Lee, J. G., Baek, I.-J., Nahm, S.-S., \& Nam, S. Y. (2019). Beta-carotene prevents the spermatogenic disorders induced by exogenous scrotal hyperthermia through modulations of oxidative stress, apoptosis, and androgen biosynthesis in mice. Korean Journal of Veterinary Research, 59(2), 59-67.

Zaharenko, M. O., Gnatjuk, S. A., Shevchenko, L. V., Poljakovskij, V. M., Mihal'skaja, V. M., \& Maljuga, L. V. (2009). Primenenie $\beta$-karotina (vitatona) dlja povyshenija vosproizvoditel'noj sposobnosti i produktivnosti zhivotnyh [The use of $\beta$-carotene (vitatone) to increase the reproductive ability and productivity of animals]. Nacional'nyj Universytet Bioresursiv i Pryrodokorystuvannia Ukrainy, Kiev (in Russian).

Zile, M. H. (2001). Function of vitamin A in vertebrate embryonic development. The Journal of Nutrition, 131(3), 705-708. 